\title{
THE RELATIONSHIP BETWEEN BEHAVIOR OF PARENT, DISCIPLINE, AND INTEREST IN LEARNING TOWARD LEARNING OUTCOME OF MATHEMATICS OF STUDENT ON SMP N 5 BANGUNTAPAN
}

\author{
Rima Nur'Afifah ${ }^{a}$, Sunaryo $^{b}$ \\ Program Studi Pendidikan Matematika Universitas Ahmad Dahlan \\ Jalan Ring Road Selatan, Tamanan, Banguntapan, Bantul Yogyakarta \\ arimaafifah20@gmail.com, ${ }^{\text {sunaryo.bener@yahoo.co.id }}$
}

\begin{abstract}
Low student learning outcomes associated with many factories. The behavior of parent, discipline, and interest in learning are some of the factors associated with learning outcomes. The aim of this study to know there or not the relationship that positive and significant between the behavior of the parent, discipline, and interest in learning by mathematics learning outcomes of student class VII the state junior high school 5 Banguntapan Regency Bantul semester even at academic year 2015/2016. The Population in this research is all of students class VII that aggregate 4 classes. The sample taken from class VII D a class of research samples with a random sampling technic toward class. The aggregation data technic is doing with the questionnaire and test method. Test of research instrument: validity test, reliability test and power of different tests. Analysis prerequisite test includes a normality test, linearity test, and independent tests. Analysis of the data is using product correlation moment analysis and multiple linear regression analysis. The result shows that there a positive and significant relation between: 1) behavior of parent by learning result of mathematics, with $\hat{Y}=-16,5147+0,6029 \mathrm{X}_{1}$; 2) discipline by learning result of mathematics, with $\hat{Y}=-23,4033+0,6410 \mathrm{X}_{2} ; 3$ ) interest in learning by learning result of mathematics, with $\hat{Y}=8,5553+0,4107 \mathrm{X}_{3}$; 4) behavior of parent and discipline by learning result of mathematics, with $\hat{Y}=-32,8843+0,2669 X_{1}+0,4879 X_{2}$ as well as SR $X_{1}=30,0072 \%$ and SR $\mathrm{X}_{2}=69,9927 \%$; 5) behavior of parent and interest in learning by learning result of mathematics, with $\hat{Y}=-29,6738+0,4842 X_{1}+0,2945 X_{3}$ along with $S R \quad X_{1}=58,9627 \%$ and $S R X_{3}=41,0373 \%$; 6) discipline and interest in learning by learning result of mathematics, with $\hat{Y}=$ $33,3746+0,5354 \mathrm{X}_{2}+0,2475 \mathrm{X}_{3}$ along with SR $\mathrm{X}_{2}=70,6966 \%$ and $\mathrm{SR} \mathrm{X}_{3}=29,3034 \%$; 7) behavior of parent, discipline and interest in learning by learning result of mathematics, with $\hat{Y}=-41,5944+$ $0,2252 X_{1}+0,4134 X_{2}+0,2306 X_{3}$ with SR $X_{1}=22,1532 \%, S R \quad X_{2}=51,891 \%$ and SR $X_{3}=25,9558 \%$.
\end{abstract}

Keywords: the behavior of parent, discipline, interest in learning, learning outcomes.

\section{INTRODUCTION}

Education is an ingrained activity for every nation. Education is a need that must be fulfilled in the process of life, especially for the Indonesian people. Through education, someone will change attitudes and behavior to mature people through the teaching and learning process. In the learning process, students face many problems that are determined by two factors, namely factors that originate from outside the student (external) and from within (internal). One external factor is parenting. According to Prihartono, Irvan. (2011: 33) revealed that parenting is an interaction between children and parents during holding care. In addition to external factors, there are internal factors that are formed in students, including discipline and interest. According to Shochib, Moh. (1998: 12), self -discipline is an essential substance in the global era to be owned and developed by children because with it he can have internal control for behavior that is always obedient to morals. Thus, the child is not swept away by the flow of globalization, but instead, he can color and accommodate. While the notion of interest according to Slameto cited by Djaali (2013: 121) says that interest is a feeling of being more like and feeling attached to a thing or activity, without being told. The mathematics learning outcomes of students in SMP N 5 Banguntapan in Bantul Regency are still low. This is because students assume that mathematics is a difficult lesson, some parents do not care about student learning activities, many parents think that children's learning activities are the responsibility of the teacher, the level of student discipline is still low, student interest in mathematics is still very less. 
The problems in this study are: 1) Is there a positive and significant relationship between parenting parents and mathematics learning outcomes of class VII students of SMP Negeri 5 Banguntapan Bantul Regency in the even semester of 2015/2016? 2) Is there a positive and significant relationship between discipline and mathematics learning outcomes of class VII students of SMPN 5 Banguntapan in Bantul Regency in the even semester of 2015/2016? 3) is there a positive and significant relationship between interest in learning and mathematics learning outcomes of class VII students of SMP Negeri 5 Banguntapan Bantul Regency even semester 2015 / 2016? old and interest in learning with the results of learning mathematics in grade VII SMP Negeri 5 Banguntapan Bantul Regency Even Semester 2015/2016 Academic Year? and significant between parenting style, discipline, and interest in learning with the mathematics learning outcomes of class VII students of SMP Negeri 5 Banguntapan, Bantul Regency, even semester 2015/2016?

The objectives of this study are 1)To find out whether there is a positive and significant relationship between parenting parents and mathematics learning outcomes of class VII students of SMP Negeri 5 Banguntapan Bantul Regency, even semester 2015/2016 academic year. positive and significant between discipline and mathematics learning outcomes of grade VII students of SMP Negeri 5 Banguntapan Bantul Regency in the academic year 2015/2016. 3) To determine whether there is a positive and significant relationship between interest in learning and the results of mathematics learning in class VII student of SMP Negeri 5 Banguntapan Bantul Regency even semester 2015/2016. 4) To find out whether there is a positive and significant relationship between parenting and discipline with the mathematics learning outcomes of class VII students at SMP Negeri 5 Banguntapan Bantul Regency, even semester 2015/2016 academic year. , 5) To find out whether there is a positive and significant relationship between p parent's care and interest in learning with mathematics learning outcomes of class VII students of Banguntapan 5 Junior High School 5 Bantul Regency in the academic year 2015/2016. 6) To determine whether there is a positive and significant relationship between discipline and interest in learning with students' mathematics learning outcomes class VII students of SMP Negeri 5 Banguntapan Bantul Regency, even semester 2015/2016. 7) To find out whether there is a positive and significant relationship between parenting style, discipline and learning interest with mathematics learning outcomes of class VII students of SMP Negeri 5 Banguntapan Bantul Regency semester even 2015/2016 academic year.

\section{THEORY}

Some opinions according to experts about the understanding of mathematics in Suherman, Erman et al (2003: 16-17) as follows: 1) According to James said that mathematics is the science of logic regarding the form, arrangement of magnitudes, and concepts that relate to one another a large number is divided into three parts, namely algebra, analysis, and geometry, 2) According to Johnson and Rising said that mathematics is a mindset, an organizing pattern, logical proof, mathematics is a language that uses carefully defined terms, clear, and accurate, representations with symbols and dense, more in the form of symbolic language about ideas than about sounds, 3) According to Reys et al. said that mathematics is the study of patterns and relationships, a way or pattern of thinking, an art, a language, and a tool, and 4) According to Kline said that mathematics is not alone knowledge that can be perfect because of him itself, but the existence of mathematics is primarily to help humans understand and master social, economic and natural problems.

According to Suherman, Erman et al (2003: 55-56), school mathematics is mathematics taught in schools, namely mathematics taught in elementary education (elementary and middle school) and secondary education (high school and vocational school). The function of mathematics subjects as tools, mindset, and science. These three functions should be used as references in learning mathematics at school. Some opinions about learning in the following: 1) Nurhayati, Eti (2010: 91) that: Learning is a process carried out by individuals to obtain changes in new behavior as a whole as a result of the individual's own experience in interacting with their environment. 2) Slameto (2010: 2) says that learning is a business process carried out by someone to obtain a new change in behavior as a whole, as 
a result of his own experience in interaction with his environment, and 3) Hamalik, Oemar (2001: 36) learning is a modification or strengthening behavior through experience.

Understanding of mathematics learning was quoted by Suherman, Erman, et al (2003: 76) from Cobb's statement that Learning mathematics is not a process of carefully packing knowledge but about organizing activities, where these activities are broadly interpreted including activities and conceptual thinking. So learning mathematics is a process in which students actively construct mathematical knowledge. Abdurrahman, Mulyono (2003: 253) from the opinion of Cornelius five reasons for the need to learn mathematics namely: 1) Means of clear and logical thinking, 2) Means to solve problems of daily life, 3) Means recognize patterns of relationships and generalization of experience, 4) Means to develop creativity, 5) Means to increase awareness of cultural developments. According to Gagne in the quote, Uno B, Hamzah (2011: 137), learning outcomes are measurable capacities of desired individual changes based on traits or inherent variables through certain teaching treatments. Whereas Hamalik, Oemar (2001: 30) revealed that "The results and evidence of one's learning is the change in behavior in someone".

Parenting consists of two words, namely pattern and foster care. In the large Indonesian dictionary that parenting has the following meanings: 1) System; how to work, 2) Fixed form (structure). While fostering has the following meanings: 1) Maintain (care for and educate) small children, 2) Guide (help, train and so on) so that they can stand alone. It can be explained that the notion of parenting is a system, how to work or form to maintain, care for, educate and guide small children so that they can stand alone. According to Nofitasari, Fanny (2015:9) dividing the form of parenting parents into 3 types of parenting namely: 1) Authoritarian parenting has characteristics: children must submit and obey the will of parents, controlling parents in children's behavior is very strict rarely give praise, often giving physical punishment in the event of failure to meet the standards set by parents, behavioral control through external control, 2) Democratic parenting has characteristics: children are allowed to be independent and develop internal control, children acknowledged as personal by parents and involved in decision making, setting rules and regulating children's lives, 3) Permissive parenting has characteristics: parental control is lacking, loose or free, children are less guided in regulating themselves, almost do not use punishment, the child is allowed to make his own decisions and can do as he wishes. From the definition of parenting form above, it can be taken good indicators of parenting parents are: 1) Children are allowed to be independent, 2) Develop internal controls, 3) Children are involved in decision making, 4) Parents set rules to regulate child's life.

Understanding of discipline according to Moenir (2006: 94) is that discipline comes from the word discipline, interpreted as punishment in a narrow sense, but discipline has a broader meaning than just punishment. A discipline is a form of obedience to the rules, both written and unwritten that have been set. Discipline characteristics in international journals written by Abdul Aziz Amir, Mochamad (2014: 6) student discipline can be seen in 3 aspects, namely: 1) Discipline aspects of students in the family environment. What is meant by family discipline is the rules at home that teach what should be and what can be done at home or in relationships with family members, 2) Discipline aspects of students in the school environment. This includes the attitude of students in the class, the presence of students, carrying out discipline in school, 3) disciplinary aspects of students in the social environment This includes: relating to lending and borrowing, which deals with time discipline. From the characteristics of discipline above, it can be taken a good indicator of discipline is 1) Attitudes of students in the class, 2) Attendance of students, 3) Carry out discipline in school.

Definition of interest according to Slameto (2010: 57) is: Interest is a fixed tendency to pay attention and remember some activities. Activities that are of interest to someone, are constantly being watched with pleasure. So it is different from attention because attention is temporary (not for a long time) and not necessarily followed by feeling happy, while interest is always followed by feelings of pleasure and from there satisfaction is obtained. While the opinion regarding interest in learning revealed by Shah, Muhibbin (2011: 133) in a simple way, interest means a tendency and high enthusiasm or a great desire for something. According to Slameto (2010: 249), students who are 
interested in learning have the following characteristics: 1) Having a fixed tendency to pay attention and remember something that is learned continuously, 2) There is a sense of liking and delight in something that is in demand, 3) Gain a sense of pride and satisfaction in what is in demand. There is an interest in something activities that are in demand, 4) More like something that interests him than others, 5) Manifested through participation in activities and activities. From the characteristics of interest in learning above, an indicator of good learning interest can be taken: 1) Attention, 2) Feelings of pleasure, 3) Interest, 4) Participation in activities.

\section{METHODS}

This research is classified as quantitative research by taking place in the State 5 of Banguntapan, Bantul Regency in the even semester of the 2015/2016 academic year. The population in this study were all students of class VII SMP Negeri 5 Banguntapan, Bantul Regency which consisted of 4 classes namely VII A, VII B, VII C, and VII D totaling 127 students. As a sample class took class VII D as many as 31 students using a random sampling technique. In this study, the data collection techniques used were questionnaires and tests. The questionnaire technique to obtain data on parenting parents, discipline and student learning interest, while the test technique is to obtain data about student mathematics learning outcomes. The test used is an analysis prerequisite test with a normality test, linearity test, and independence test. In this study, the hypothesis test used is regression analysis.

\section{RESULTS AND DISCUSSION}

\section{Parenting Parents}

Table 1. Distribution of Number of Students by Category Score of Parenting Parents

\begin{tabular}{|c|c|c|c|}
\hline Category & Score & $\boldsymbol{F}$ & \% \\
\hline High & $\mathrm{X}>108,62$ & 3 & 9,68 \\
\hline Medium & $90,35 \leq \mathrm{X} \leq 108,62$ & 24 & 77,42 \\
\hline Low & $\mathrm{X}<90,35$ & 4 & 12,9 \\
\hline \multicolumn{2}{|c|}{ Total } & 31 & 100 \\
\hline
\end{tabular}

From the categorization results, it can be seen that the parenting style of the VII D class of SMP Negeri 5 Banguntapan Bantul in 2015/2016 Academic Year is included in the medium category because the highest frequency lies in the interval $90,3484 \leq X \leq 108,6194$ which is 24 students or $77,4194 \%$

\section{Discipline}

Table 2. Distribution of Number of Students by Category Discipline score

\begin{tabular}{|c|c|c|c|}
\hline Category & Score & $\boldsymbol{F}$ & \% \\
\hline High & $\mathrm{X}>113,91$ & 7 & 22,58 \\
\hline Medium & $94,38 \leq \mathrm{X} \leq 113,91$ & 21 & 67,74 \\
\hline Low & $\mathrm{X}<94,38$ & 3 & 9,68 \\
\hline \multicolumn{2}{|c|}{ Total } & 31 & 100 \\
\hline
\end{tabular}

From the categorization results, it can be seen that the discipline of class VII D SMP Negeri 5 Banguntapan Bantul 2015/2016 Academic Year is included in the medium category because the highest frequency is located at $94.38 \leq \mathrm{X} 113.91$ which is 21 students or $67.74 \%$.

\section{Interest in Learning}

Table 3. Distribution of Number of Students by Category Score of interest in learning

\begin{tabular}{|c|c|c|c|}
\hline Category & Score & $F$ & $\%$ \\
\hline High & $X>106.10$ & 2 & 6,45 \\
\hline Medium & $50,42 \leq \mathrm{X} \leq 106.10$ & 29 & 93,55 \\
\hline Low & $X<50,42$ & 0 & 0 \\
\hline \multicolumn{2}{|r|}{ Total } & 31 & 100 \\
\hline
\end{tabular}


From the categorization results, it can be seen that the discipline of class VII D SMP Negeri 5 Banguntapan Academic Year 2015/2016 is included in the medium category because the highest frequency is located at $50.42 \leq \mathrm{X} \leq 106.10$ which is 29 students or $93.55 \%$.

\section{Mathematics learning outcomes}

Table 4.Distribution of Number of Students by Category Score in Mathematics Learning Outcomes

\begin{tabular}{|c|c|c|c|}
\hline Category & Score & $\boldsymbol{F}$ & \% \\
\hline High & $\mathrm{X}>55,38$ & 7 & 22,58 \\
\hline Medium & $30,85 \leq \mathrm{X} \leq 55,38$ & 20 & 64,52 \\
\hline Low & $\mathrm{X}<30,85$ & 4 & 12,9 \\
\hline \multicolumn{2}{|c|}{ Total } & 31 & 100 \\
\hline
\end{tabular}

From the categorization results, it can be seen that the mathematics learning outcomes of class VII D SMP Negeri 5 Banguntapan Academic Year 2015/2016 are included in the medium category because the greatest frequency lies in the interval $30.85 \leq X \leq 55.38$ which is 20 students or $64.52 \%$.

\section{a. Normality test}

Table 5. Summary of Normality Test Results

\begin{tabular}{|l|c|l|l|l|}
\hline \multicolumn{1}{|c|}{ Category } & $\boldsymbol{x}_{\text {stat }}^{\mathbf{2}}$ & $\boldsymbol{x}_{\text {table }}^{\mathbf{2}}$ & $\mathbf{d f}$ & Conclusion \\
\hline Parenting parents & 5,1289 & 5,9915 & 2 & Normal \\
\hline Discipline & 4,0885 & 9,4877 & 4 & Normal \\
\hline Interest to learn & 5,6327 & 5,9915 & 2 & Normal \\
\hline Learning outcomes & 4,4098 & 7,8147 & 3 & Normal \\
\hline
\end{tabular}

b. Linearity Test

Table 6. Summary of Linearity Test Results

\begin{tabular}{|c|c|c|c|}
\hline Variable & $\mathbf{F}_{\text {cal }}$ & $\mathbf{F}_{\text {table }}$ & Conclusion \\
\hline $\mathrm{X}_{1}$ to $\mathrm{Y}$ & 1,5153 & 2,67 & Linear \\
\hline $\mathrm{X}_{2}$ to $\mathrm{Y}$ & 1,1385 & 2,94 & Linear \\
\hline $\mathrm{X}_{3}$ to $\mathrm{Y}$ & $-0,3570$ & 2,67 & Linear \\
\hline
\end{tabular}

c. Idenpendent Test

Table 7. Summary of Independence Test Results

\section{d. Hypothesis Test}

\begin{tabular}{|l|l|l|l|l|}
\hline Variable & $\boldsymbol{x}_{\text {cal }}^{2}$ & $\boldsymbol{x}_{\text {table }}$ & Df & Conclusion \\
\hline $\mathrm{X}_{1}$ and $\mathrm{X}_{2}$ & 36,797 & 37,625 & 25 & independent \\
\hline $\mathrm{X}_{1}$ and $\mathrm{X}_{3}$ & 32,333 & 37,625 & 25 & independent \\
\hline $\mathrm{X}_{2}$ and $\mathrm{X}_{3}$ & 32,594 & 37,625 & 25 & independent \\
\hline
\end{tabular}

Table 8. Summary of hypothesis test results

\begin{tabular}{|c|c|c|cc|c|}
\hline Hypothesis & $\mathbf{T}_{\text {cal }}$ & $\mathbf{t}_{\text {table }}$ & Df & Information \\
\hline 1 & 2,4078 & 1,6991 & 29 & $\mathrm{H}_{0}$ rejected \\
\hline 2 & 2,9103 & 1,6991 & 29 & $\mathrm{H}_{0}$ rejected \\
\hline 3 & 2,0804 & 1,6991 & 29 & $\mathrm{H}_{0}$ rejected \\
\hline 4 & 4,1566 & 3,34 & $\mathrm{~V}_{1}=2$ & $\mathrm{~V}_{2}=28$ & $\mathrm{H}_{0}$ rejected \\
\hline 5 & 4,1094 & 3,34 & $\mathrm{~V}_{1}=2$ & $\mathrm{~V}_{2}=28$ & $\mathrm{H}_{0}$ rejected \\
\hline 6 & 5,1014 & 3,34 & $\mathrm{~V}_{1}=2$ & $\mathrm{~V}_{2}=28$ & $\mathrm{H}_{0}$ rejected \\
\hline 7 & 3,5160 & 2,96 & $\mathrm{~V}_{1}=3$ & $\mathrm{~V}_{2}=27$ & $\mathrm{H}_{0}$ rejected \\
\hline
\end{tabular}




\section{CONCLUSION}

1. There is a positive and significant relationship between parenting parents and mathematics learning outcomes of class VII students of Banguntapan 5 Middle School in Bantul Regency, even semester $2015 / 2016$ academic year. This is indicated by the $t$-test which is $t_{\text {cal }}>t_{\text {table }}$ or $2.4078>1.6991$. The simple correlation coefficient ( $r$ ) between interest in learning and mathematics learning outcomes is 0.4082 . As well as a simple regression equation $\mathrm{Y}$ over $\mathrm{X}_{1}$ is $\hat{\mathrm{Y}}=-16,5147+0,6029 \mathrm{X}_{1}$.

2. There is a difference between a positive and significant relationship between discipline and the mathematics learning outcomes of class VII students at Banguntapan 5 Middle School in Bantul Regency, even semester 2015/2016. This is indicated by the t-test which is $t_{\text {cal }}>t_{\text {table }}$ or 2.9103> 1.6991. The simple correlation coefficient ( $\mathrm{r}$ ) between discipline and mathematics learning outcomes of 0.4754 . In addition, also obtained a simple regression equation $\mathrm{Y}$ over $\mathrm{X}_{2}$ is $\hat{\mathrm{Y}}=$ $23,4033+0,6410 \mathrm{X}_{2}$.

3. There is a positive and significant relationship between interest in learning with the mathematics learning outcomes of VII semester students of Banguntapan 5 Middle School in the academic year $2015 / 2016$. This is indicated by the $t$-test, namely $t_{\text {cal }}>t_{\text {table }}$ or 2.0804> 1.6991. A simple correlation coefficient ( $\mathrm{r}$ ) between the learning environment and mathematics learning outcomes is 0.3604. In addition, also obtained a simple regression equation $Y$ on $X_{3}$ is $\hat{Y}=8,5553+0,4107 X_{3}$.

4. There is a positive and significant relationship between parenting style and discipline with the mathematics learning outcomes of class VII students of Banguntapan 5 Middle School in Bantul Regency even semester 2015/2016 academic year. This is indicated by the $F$ test which is $F_{\text {stat }}>$ $\mathrm{F}_{\text {table }}$ or 4,5623> 3.34 Multiple correlation coefficient $(\mathrm{R})$ between parenting style and discipline with mathematical learning outcomes of 0.4958 and coefficient of determination $\left(\mathrm{R}^{2}\right)$ of 0.2458 with linear line equations $\hat{\mathrm{Y}}=-32,8843+0,2669 \mathrm{X}_{1}+0,4879 \mathrm{X}_{2}$. The relative contribution of $\mathrm{X}_{1}$ is $58.8916 \%$ and $X_{2}$ is $41.1084 \%$ and the effective contribution of $X_{1}$ is $13.48025 \%$ and $X_{2}$ is $9.4109 \%$.

5. There is a positive and significant relationship between parenting style and interest in learning with mathematics learning outcomes of class VII students of Banguntapan 5 Middle School in Bantul Regency, even semester 2015/2016 academic year. This is indicated by the F test which is $F_{\text {stat }}>$ $\mathrm{F}_{\text {table }}$ or 4.1094> 3.34. The correlation coefficient $(\mathrm{R})$ between parenting style and interest in learning with mathematics learning outcomes of 0.4764 and coefficient of determination $\left(\mathrm{R}^{2}\right)$ of 0.2270 with linear line equations $\hat{Y}=-29,6738+0,4842 X_{1}+0,2945 X_{3}$. The relative contribution of $X_{1}$ is $58,9627 \%$ and $X_{3}$ amounted to $41.0373 \%$ and the effective contribution of $X_{1}$ was $13.3798 \%$ and $\mathrm{X}_{3}$ was $9.3122 \%$

6. There is a positive and significant relationship between discipline and interest in learning with the mathematics learning outcomes of class VII students of Banguntapan 5 Middle School in Bantul Regency, even semester 2015/2016 academic year. This is indicated by the F test, which is $F_{\text {stat }}>$ $\mathrm{F}_{\text {table }}$ or 5.1014> 3.34. The correlation coefficient $(\mathrm{R})$ between discipline and interest in learning with mathematical learning outcomes is 0.5168 and the coefficient of determination $\left(\mathrm{R}^{2}\right)$ is 0.2671 with linear line equations $\hat{Y}=-33,3746+0,5354 X_{2}+0,2475 X_{3}$. The relative contribution of $X_{2}$ is $70,6966 \%$ dan $\mathrm{X}_{3}$ amounted to $29,3033 \%$ and the effective contribution $\mathrm{X}_{2}$ is $18,8809 \%$ and $\mathrm{X}_{3}$ was $7,8260 \%$.

7. There is a positive and significant relationship between parenting style, discipline, and interest in learning with the mathematics learning outcomes of class VII students of Banguntapan 5 Middle School in Bantul Regency, even semester 2015/2016. This is indicated by the F test which is $F_{\text {stat }}>$ $\mathrm{F}_{\text {table }}$ or 3.5160> 2.96. Correlation coefficient $(\mathrm{R})$ between parenting style, discipline and interest in learning with mathematics learning outcomes of 0.5300 and coefficient of determination $\left(\mathrm{R}^{2}\right)$ of 0.2809 with linear line equations $\hat{Y}=-41,5944+0,2252 X_{1}+0,4134 X_{2}+0,2306 X_{3}$. The relative contribution of $X_{1}$ is $22,1532 \%, X_{2}$ amounted to $51,8910 \%$ and $X_{3}$ is $25,9558 \%$ and the effective contribution $\mathrm{X}_{1}$ is $6,2233 \%, \mathrm{X}_{2}$ is $14,5773 \%$ and $\mathrm{X}_{3}$ is $7,2916 \%$. 


\section{REFERENCES}

Abdurrahman, Mulyono. 2003. Pendidikan bagi Anak Berkesulitan Belajar. Jakarta: Rineka Cipta.

Abdul Aziz Amir, Mochamad. 2014. Pendekatan Konseling Kelompok Rational Emotive Behavioural Therapy dalam Meningkatkan Kedisiplinan Siswa. Jurnal. - : Universitas pendidikan Indonesia.

Diakses pada tanggal $13 \quad$ Mei 2016 dari: http://www.academia.edu./12168232/PENDEKATAN KONSELING KELOMPOK RATION AL_EMOTIVE_BEHAVIOURAL_THERAPY_DALAM_MENINGKATKAN_KEDISIPLIN AN_SISWA

Djaali. 2013. Psikologi Pendidikan. Jakarta: Bumi Aksara.

Hamalik, Oemar. 2001. Kurikulum dan Pembelajaran. Jakarta : Bumi Aksara.

Prihartono, Irvan. 2011. Pola Asuh Asuh, Persepsi Tentang Iklim Kelas dan Sikap Kreatif Anak Sekolah Alam Kandag Jurang Doang. Jurnal. Jakarta. Universitas Islam Negeri Syarif Hidayatullah. Diakses pada tanggal 29 Juli 2016 dari:http://www.definisipengertian.com/2015/05/definisidan-pengertian-pola- asuh.html?m=1

Moenir.2006. Manajemen Pelayanan Umum Indonesia.Jakarta:Bumi Aksara.

Nofitasari, Fanny. 2015. Hubungan antara Pola Asuh Orang Tua yang memiliki Anak berkebutuhan Khusus dengan Kemandirian pada Anak di SLB Harapan Mandiri Palembang. Jurnal. Palembang: Universitas Bina Darma Palembang. Diakses pada tanggal 13 Mei 2016 dari : http://digilib.binadarma.ac.id/download.php?id=723

Nurhayati, Eti. 2010. Psikologi Pendidikan Inovatif. Jakarta: Rineka Cipta.

Shochib, Moh. 1998. Pola Asuh Orang Tua untuk membantu Anak Mengembangkan Disiplin Diri. Jakarta : Rineka Cipta.

Slameto. 2010. Belajar \& Faktor-faktor yang Mempengaruhinya. Jakarta: Rineka Cipta.

Suherman, dkk. 2003. Strategi Pembelajaran Matematika Kontemporer. Jakarta : Universitas Pendidikan Indonesia.

Syah, Muhibbin. 2011. Psikologi Pendidikan. Bandung: PT Remaja Rosdakarya Offset.

Uno, Hamzah. 2011. Model Pembelajaran Menciptakan Proses Belajar Mengajar yang Kreatif dan Efektif. Jakarta: Bumi Aksara. 